\title{
8.8. ПРЕИМУЩЕСТВА И НЕДОСТАТКИ ГРУППЫ БРИКС: АЛЬТЕРНАТИВНЫЙ ВЗГЛЯД
}

Фрумина С.В., к.э.н., доцент, Департамент общественных финансов

\author{
ФГОБУ ВО «Финансовый университет при Правительстве РФ», г. Москва
}

В статье рассмотрены тенденции развития стран - членов БРИКС с позиции их инновационного, инвестиционного и торгового потенциала. Акцент делается на взаимовыгодных сторонах сотрудничества внутри объединения, обосновываются конкурентные преимущества и достоинства каждой из стран. Особое внимание уделяется негативным факторам развития членов БРИКС, которые в будущем могут представлять значительные угрозы объединению.

\section{Литература}

1. Об утверждении Стратегии инновационного развития РФ на период до 2020 г. [Электронный ресурс] : распоряжение Правительства РФ от 8 дек. 2011 г. №2227-р. Доступ из справ.-правовой системы «Консультант Плюс».

2. Ахмадеев Р.Г. Изменение структуры внешней задолженности по странам БРИкС [Текст] / Р.Г. Ахмадеев, О.А. Быканова // Азимут научных исследований: экономика и управление. - 2017. - Т. 6 ; №1. - С. $22-26$.

3. Внешняя торговля России [Электронный ресурс]. - https://russian-trade.com/news/2018-07/pokazatelivneshnetorgovogo-oborota-rossii-so-stranami-briks-prodolzhayut-rasti/

4. Косов М.Е. Зарубежный опыт предоставления гарантий для реализации инвестиционных проектов [Текст] / М.E. Косов // Финансы и кредит. - 2019. - Т. 25 ; №25. - С. 392-408.

5. Страны БРИКС: классификация регионов [Электронный ресурс] // Бюллетень о текущих тенденциях мировой экономики. - 2018. - Июль. - URL : http://ac.gov.ru/files/publication/a/17363.pdf

6. Ревенко Л.С. Взаимная торговля стран БРИКС: потенциал и направления развития [Текст] / Л.С. Ревенко, Н.С. Ревенко // Российский внешнеэкономический вестник. - 2018. - №10. - С. 70-81.

7. Резванова Д.Б. и др. Перспективы развития и взаимодействия экономик стран БРИКС. Российско-китайские отношения как альтернатива западного вектора России [Электронный ресурс] / Д.Б. Резванова, А.А. Мальцев, В.А. Мальцева. - URL : http://elar.urfu.ru/bitstream/10995/ 34472/1/urrr_2015_94.pdf

8. Уровень жизни в странах мира, рейтинг 2019 года [Электронный ресурс]. - URL : https://basetop.ru/uroven-zhizni-vstranah-mira-rejting-2019-goda/

9. Шатская И.И. Перспективы развития БРИКС [Электронный ресурс] / И.И. Шатская // Науч. альманах. - 2016. - №4-1. C. 307-311. - URL : http://ucom.ru/doc/na.2016.04.01.307.pdf

10. Dutta S. et al. Global innovation index 2019 [Electronic resource] / S. Dutta, B. Lanvin, S. Wunsch-Vincent. - URL : https://nonews.co/wpcontent/uploads/2019/08/gii2019.pdf

11. SWOT analysis of BRICS financial cooperation [Electronic resource]. - URL : https://ozziessay.com.au/essay-on-swotanalysis-of-brics-financial-cooperation/

12. World investment report 2019 [Electronic resource]. - URL : https://worldinvestmentreport.unctad.org/worldinvestment-report2019/

\section{Ключевые слова}

БРИКС; инвестиции; инновации; цифровая экономика; социально-экономическое развитие.

\section{Фрумина Светлана Викторовна}

\section{РЕЦЕНЗИЯ}

Рецензируемая статья безусловно, носит актуальный характер в связи с продолжающимися внешними угрозами со стороны западных экономик и политических режимов. Взаимное сотрудничество в рамках объединения БРИкС, как показано автором в работе, позволит усилить конкурентные преимущества и предложить достойную альтернативу взаимодействия с другими государствами на более привлекательных условиях.

Автором статьи рассматриваются преимущества и недостатки участников группы БРИкС, частично нашедшие отражение в тематических работах отечественных и зарубежных исследователей. Однако интересным представляется анализ инновационной и инвестиционной привлекательности стран-участниц и их позиции в соответствующих рейтингах.

Несомненной заслугой автора является выделение угроз и возможных преимуществ государств, отмеченная взаимодополняемость экономик с точки зрения их отраслевой направленности. Автором справедливо фрормулируются выводы, касающиеся социальноэкономического развития государств-членов БРИКС.

Предлагаемые в работе уточнения в государственные программы позволят синхронизировать национальные документы стратегического планирования, повысить инновационный потенциал государства, поскольку рассматриваемые показатели являются непосредственными характеристиками развития цифровой и инновационной экономики.

Вместе с тем, следует отметить, что при построении матрицы SWOT- анализа можно было оперировать большим количеством характеристик, которые усилили бы исследовательскую компоненту статьи. Однако данный недостаток не снижает общее положительное впечатление от работы.

В целом, статья отражает владение автора вопросами исследуемой проблемы, содержит конкретные предложения по решению рассматриваемых вопросов и может быть опубликована в рецензируемом научном журнале.

Журавлева Т.А., Доктор экономических наук, профессор, Професссор кафедры «Экономическая теория и управление персоналом», ФГБОУ ВО «Орловский государственный университет им. И.С. Тургенева», г. Орел.

DOI 10.38097/AFA.2020.72.86.032 
